\title{
Sensory evaluation for consumer acceptance testing of Sabalito pigeon pea (Cajanus cajan) stew in Costa Rica
}

\author{
Carmén Andrés Jiménez \\ Universidad Estatal a Distancia (UNED), Apdo. 474-2050 Mercedes de Montes de Oca, San José, Costa Rica; candres@uned.ac.cr
}

Received 7-XI-2012 Corrected 4-III-2013 Accepted 16-IV-2013

\begin{abstract}
The pigeon pea is widespread in Latin America, Asia and Africa and exported to the USA and Europe. Pigeon pea is a nitrogen fixer, has high nutritional value and protects water basins. There are four main varieties that grow in San Carlos, Costa Rica: Catie, Sabalito, Folk and Panama. A sensory evaluation for consumer acceptance testing was done with 33 consumers, using a 9-point hedonic scale (overall likability to extreme dislikability) to determine the level of acceptance of a Sabalito pigeon pea ham and potato crockpot stew. Acceptance was: Overall likability $27,3 \%$ of consumers, high $45,5 \%$, moderate $24,3 \%$ and slight $3,03 \%$. Consumers who liked condiment content also liked the appearance of the produce and those who liked the salt content, also liked the condiment content (Spearman correlation). Consumers' grades were divided in two groups through a cluster analysis $(8,13$ and 6,89$)$. Overall acceptance was high $(72,7 \%)$ and I recommend pilot plant tests, and physical, chemical and more sensorial analyses before launching the product to the Costa Rican market.
\end{abstract}

\section{KEY WORDS}

Pigeon pea, Cajanus cajan, consumer acceptance, sensory evaluation, hedonic scale

\begin{abstract}
RESUMEN
Prueba de aceptación sensorial para un guiso de frijol gandul variedad Sabalito (Cajanus cajan) en Costa Rica. El frijol gandul es conocido en América Latina, Asia y África y exportado a Estados Unidos y Europa. Se ha estudiado de forma reciente por la UNED a través de productores que residen en San Carlos, Costa Rica. El gandul es un fijador de nitrógeno, tiene un alto valor nutricional y protege cuencas hidrográficas. Existen cuatro variedades principales que crecen en San Carlos: Catie, Sabalito, Criolla y Panamá. Una prueba sensorial de aceptación se realizó con 33 consumidores, utilizando una escala hedónica de 9 puntos (gusta demasiado a disgusta demasiado) para determinar el nivel de aceptación de un guiso elaborado a partir de gandul variedad Sabalito con papa y jamón. El atributo "me gusta demasiado" abarcó un 27,3\% de los consumidores, me gusta mucho un $45,5 \%$, me gusta moderadamente un $24,3 \%$ y me gusta ligeramente un $3,03 \%$. El contenido de condimentos y la apariencia así como la cantidad de sal y el contenido de condimentos están correlacionados (prueba de Spearman). Las calificaciones de los consumidores en la escala hedónica se dividieron en dos grupos a través de un análisis de conglomerados(8,13 and 6,89). Como conclusión, el gandul gustó mucho para la mayoría de los consumidores (72,7\%). Se necesita hacer más pruebas en pruebas piloto y análisis físico-químicos, microbiológicos y sensoriales para poder lanzar el producto al mercado, junto con estudios de comercialización.
\end{abstract}

\section{PALABRAS CLAVE}

Gandul, Cajanus cajan, prueba de aceptación, análisis sensorial, escala hedónica
The Pigeon pea bean is a legume, its origin believed to be in Asia. It is widespread throughout the world and its properties are very diverse since the plantation can protect watersheds, can fix Nitrogen into the soil, serves as a fertilizer wherever is sown (Liberterre, ND). It also has high nutritional value ( 18 to $25 \%$ of protein, oligoelements and vitamins A and C (González, 2012).
Due to its high nutritional value, pigeon pea bean can be used to substitute wheat. For example, a test substituting $30 \%$ of wheat with Pigeon pea bean was done in an investigation in Venezuela, improving the texture of the product (Granito, Valero \& Zambrano, 2010).

The gandul bean Project leaded by the National Distance State University (UNED in Spanish), has been working 
for four years developing new plantations of eight varieties of Pigeon pea in 12 farms of San Carlos, Costa Rica. Out of those varieties the most important are Catie, Folk, Sabalito and Panama. The farmers plant different products and sell them to small retailers, but pigeon pea is a product that might help them improve their profit and their quality of life.

Products industrialized from pigeon pea are being sold around the world in Dominican Republic, Puerto Rico, Panama, Peru, United States and Europe. The most common products are canned tender pigeon pea and frozen tender pigeon pea.

Recently, new product development efforts have also been made by the Agro industrial Engineering Department in Costa Rica and this study is one of them. The crockpot stew that was used was a suggestion of consumption, so that the consumers would know what pigeon pea tasted like.

Other efforts have been made to determine the best way to develop products made from pigeon pea, such as a general focus group to determine the best products to be industrialized and another mini focus group to determine if a specific product is accepted or not (Andrés, 2013).

Since this legume is planted without chemicals, has such a high nutritional content and has all the goodness mentioned above, it has been classified by the focus groups as a natural, environment friendly and convenience product.

The main objective of this investigation was to determine the level of likability Costa Rican consumers had for Sabalito pigeon pea, made in a crockpot ham and potato stew through a sensorial acceptance testing.

\section{METHODOLOGY}

This study is the first acceptance testing performed for pigeon pea (Cajanus cajan) in Costa Rica. This method is used to determine whether the consumer accepts the product being developed or not. This test is usually performed with the nine point hedonic scale (Carpenter, Lyon \&Hasdell, 2000).

Other studies have also evaluated acceptance of consumers with the method used in this investigation. Malgarejo and Maury (2002) evaluated a hamburger made from Prochylodus nigricans using this test. Resureccion (2004) used an acceptance testing to determine consumer choices for meat and meat products. And Platter, Tatum, Belk, Chapman, Scanga and Smith (2003) used a hedonic scale to evaluate tenderness, juiciness and flavour of steak.
A sensory evaluation for consumer acceptance testing was done with 33 consumers, using a 9-point hedonic scale (overall likability to extreme dislikability) to determine the level of acceptance of a Sabalito crockpot pigeon pea, ham and potato stew.

The description of the method is as follows:

\section{Call for participants}

The acceptance testing was informed to the members of the Exact and Natural Sciences faculty of UNED. Thirtythree people agreed to participate in the test.

\section{Defining formulation of product}

Different tests were made to determine the correct time of cooking for the Sabalito pigeon pea, but 10 hours in a slow crock pot was the best choice.

The ingredients were also tasted in three rehearses until the best formulation was defined, which cannot be revealed.

\section{Preparation of samples}

A crockpot stew made of pigeon pea, potato and ham was made and served in small plastic plates with a spoon, a napkin and water.

Each participant could eat the whole portion or only the necessary to determine their general acceptance of the product.

\section{Attributes to evaluate}

Salt content, condiment content and appearance were the three attributes evaluated during this test using two tools:

A hedonic scale of 9 points: This scale was designed with the following characteristics: Overall dislikability, High dislikability, Moderated dislikability, Slight dislikability, Don't like it or dislike it, Slightlikability, Moderate likability, Highlikability, Overall likability.

The person had to mark for all attributes the descriptor that best fit their perception of the product.

A descriptive analysis based on an open question: Participants had to tell what ingredients they would take away, which to add and any other comments they had on the product, was done along with the acceptance testing.

\section{Statistical analysis}

A Spearman correlation was applied to determine association between attributes (salt, appearance and 
condiment content) and a two-phase cluster analysis was done to determine the amount of groups in which consumers can be divided and their characteristics.

\section{RESULTS}

As a general result, the acceptance of the Sabalito Pigeon pea ham and potato stew in a nine point hedonic scale was 7,78 (9 is the highest). Overall likability (27,3\% of the consumers), highlikability (45,5\% of the consumers), moderate likability (24,3\% of the consumers) and slight likability (3,03\% of consumers).

\section{Hedonic scale results}

Figures 1 to 3 show the results obtained for each of the attributes evaluated through and hedonic scale ( 1 equals 9 in the hedonic scale, 2 equals 8, 3 equals 7, 4 equals 6 and 5 equals 5 ).

\section{Statistical analysis}

Consumers who liked condiment also liked the amount of salt $(p<0,01)$ and consumers who liked condiment, also liked appearance $(p<0,05)$.

According to a two-phase cluster analysis, consumers were divided into two groups. One with 24 consumers and the other with 9 consumers. The size coefficient was 2,67.

\section{Open question results}

The most important ingredients almost $50 \%$ of people mentioned should be added to the recipe were the foIlowing: red pepper, hot pepper, onion, dill, other type of meat (pork, beef, chicken), more vegetables and an ingredient that enhances the flavour (see appendix 1 for more information).

On the other hand, the ingredients that weren't liked by no more than $9 \%$ of the consumers were: ham, salt and big potato pieces (they wanted them smaller).

\section{DISCUSSION}

In this study the Sabalito pigeon pea ham and potato stew had a high acceptance by Costa Rican consumers. Innovative products made from pigeon pea in general have been studied by other authors, with a high acceptance as well. The most recent studies have been done on cookies
(Okpala, Okoli \& Udensi, 2013) and biscuits (Tiwari, Brennan, Jaganmohan, Surabi \& Alagusundaram; 2011).

Nevertheless, a study done by Rampersad, Badrie and Comissiong (2003) found a moderate to high likability of flavoured snacks from extruded cassava/Pigeonpea flour, which means pigeon pea is not always accepted the way it was in this study.

Aside from the general acceptance obtained, the information gathered from the consumers about what they

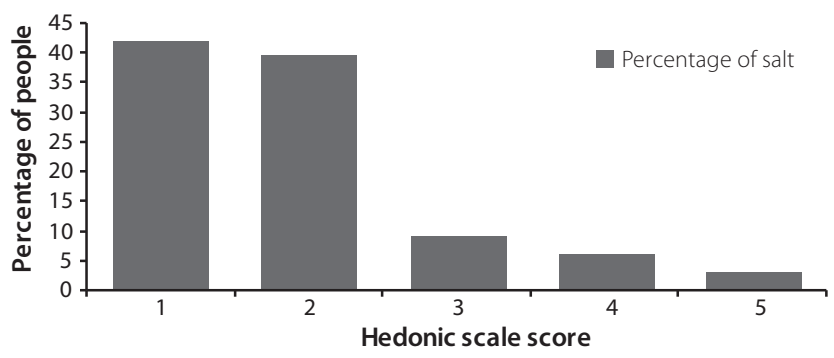

FIG. 1. Acceptance of the salt content in the crock pot pigeon pea potato and ham strew evaluated by 33 consumers. Standard deviation of 1,023 .

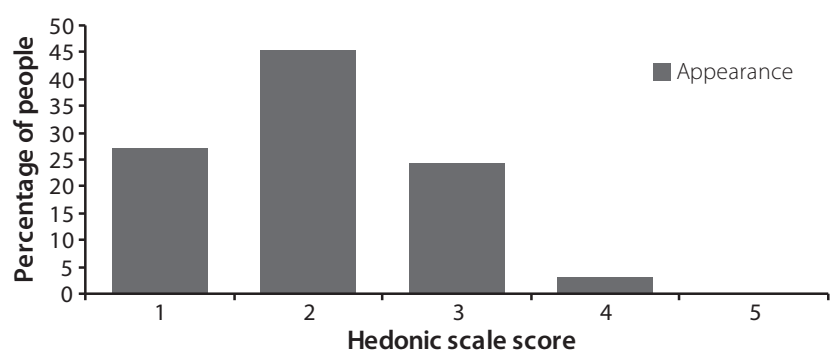

FIG. 2. Acceptance of the appearance in the crock pot pigeon pea potato and ham strewt evaluated by 33 consumers. Standard deviation of 1,1661.

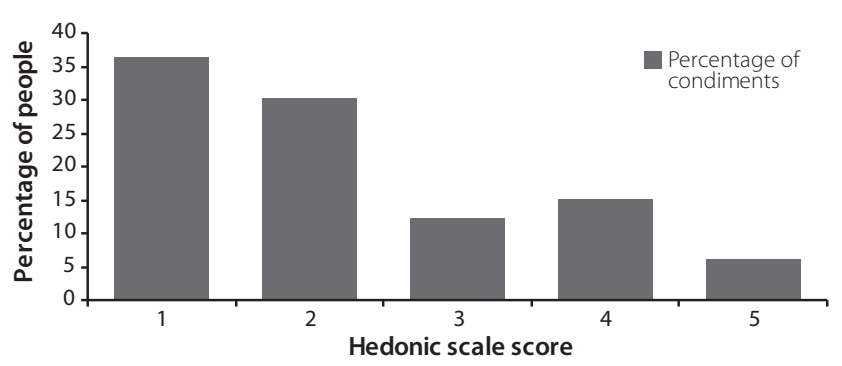

FIG. 3. Acceptance of the condiment content in the crock pot pigeon pea potato and ham strew evaluated by 33 consumers. Standard deviation of 2,19. 
liked and disliked is a hint for the products that can be made from pigeon pea, about what to try and what not to try in a large scale. It also shows how pigeon pea is a very versatile legume as can be seen in the recent studies mentioned above.

The fact that the percentaje of condiments and amount of salt were liked the most by consumers, but not the appearance of the product coincides with another study done by Andrés, Amerling \& Saravia (2013), about a salad and a dip made from Cajanus cajan, in which appearance still needs to be improved.

The mixture of turkey ham and pigeon pea was also rejected by a group of customers which performed a mini focus group about a specific product made from pigeon pea and turkey ham. Pork ham was the one consumers recommended (Andrés, 2013).

Above all the results discussed, the fact that the general likabilitywas among overall and high, fulfils the goal of the study and gives a green light to continue investigating different varieties of pigeon pea and their acceptance and preference among Costa Rican consumers.

\section{RECOMMENDATIONS}

- A simpler recipe should be done for the next acceptance testing made with pigeon pea, so that the content and kind of condiments isn't an issue.

- This is only the beginning of the new product development process. A market study has to be done in San Carlos, in order to determine the acceptance the consumer will have of pigeon pea itself and what products can really be sold.

- Physical and chemical analysis need to be done to the products defined in the market study that is going to be manufactured and sold.

- Pilot plant and more sensorial analysis (differential testing, triangle testing) and industrialization tests need to be done in order to improve the formulation of the product according to the results from these tests.

\section{REFERENCES}

Andrés, C. (2013). Determinación de los descriptores sensoriales de un producto untable tipo hummus a base de la variedad criolla de gandul (Cajanus cajan) mediante dos mini grupos focales. Cuadernos de Investigación, in press.

Andrés, C; Amerling, C. \& Saravia, K. (2013).Prueba sensorial de grado de satisfacción para una ensalada y un dip tipo hummus elaborados a base de gandul (Cajanus cajan (L.) Millsp.). Repertorio Científico UNED, in press.
Carpenter, R., Lyon, D. \& Hasdell, T. (2000). Guidelines for sensory analysis in food product development and quality control. Gaithersburg, MD, USA: Aspen Publishers Inc. Retrieved from http://books.google.co.cr/books?hl=es $\& \mid r=\& i d=a k l z b g k T K 7 g C \& o i=$ fnd \&pg $=$ PR1 1 \&dq=Accept ance+testing, +sensorial+analysis\&ots $=c y-f 8 F G I d$ $\mathrm{N} \&$ sig = d7Tc6ZV-cu-vU2MToY9T4tYp_gE\&redir_ esc $=\mathrm{y} \# \mathrm{v}=$ onepage $\& \mathrm{q}=$ Acceptance $\% 20$ testing $\% 2 \mathrm{C} \% 20$ sensorial\%20analysis\&f=true

González, L. (2012). Gandul. Personal Communications, 29 June 2012, Agronomy Engineer. Distance State University (UNED), San José, Costa Rica.

Granito, M., Valero, Y. \& Zambrano, R. (2010). Desarrollo de productos horneados a base de leguminosas fermentadas y cereales destinados a la merienda escolar. Archivos Latinoamericanos de Nutrición, 60(1), 85-92.

Liberterre. (ND). Gandul: clasificación botánica. Retrieved from http://www.liberterre.fr/gaiagnostic/semillas/gandul bean.html

Luckow, T. \& Delahunty, C. (2004). Consumer acceptance of orange juice containing functional ingredients. Food Research International, 37(8),805-814. Retrieved fromhttp://www.sciencedirect.com/science/article/pii/ S0963996904000924

Malgarejo, I. \& Maury, M. (2002). Elaboración de hamburguesa a partir de Prochylodus nigricans "boquichico". Revista Amazónica de Investigación Alimentaria, 2(1),79-87. Retrieved fromhttp://www.unapiquitos.edu.pe/links/facultades/ alimentarias/v21/8.pdf

Okpala, L., Okoli, E.,\& Udensi, E. (2013). Physico-chemical and sensory properties of cookies made from blends of germinated pigeon pea, fermented sorghum, and cocoyam flours. Food Science \& Nutrition, 1(1), 8-14. Retrieved from: http:// onlinelibrary.wiley.com/doi/10.1002/fsn3.2/full

Platter, W., Tatum, J., Belk, E., Chapman, P., Scanga, J. \& Smith, G. (2003). Relationships of consumer sensory ratings, marbling score and shear force value to consumer acceptance of beef strip loin steaks. Journal of Animal Science, 81(11),2741-2750. Retrieved fromwww.ncbi.nlm.nih.gov/ pubmed/14601877

Rampersad, R., Badrie, N. \& Comissiong, E. (2003). Physico-chemical and Sensory Characteristics of Flavored Snacks from Extruded Cassava/Pigeonpea Flour. Journal of Food Science, 68 (1), 363-367.

Resurreccion, A. (2004). Sensory aspects of consumer choices for meat and meat products. Meat Science, 66 (1),11-20. Retrieved from http://www.sciencedirect.com/science/ article/pii/S0309174003000214

Tiwari, B., Brennan, C., Jaganmohan, R., Surabi, A.,\& Alagusundaram, K. (2011). Utilisation of pigeon pea (Cajanus cajan L) byproducts in biscuit manufacture. Food Science and Technology, 44 (6), 1533-1537. Retrieved from: http://www.sciencedirect.com/science/article/pii/ S0023643811000326. 